LLymp9904008

\title{
Humid Air Corrosion of YMP Waste Package Candidate Materials
}

\author{
Gregory E. Gdowski
}

This paper was prepared for submittal to the

\author{
CORROSION NACExpo 98 \\ San Diego, $C A$ \\ March 22-27, 1998
}

\section{March 1998}

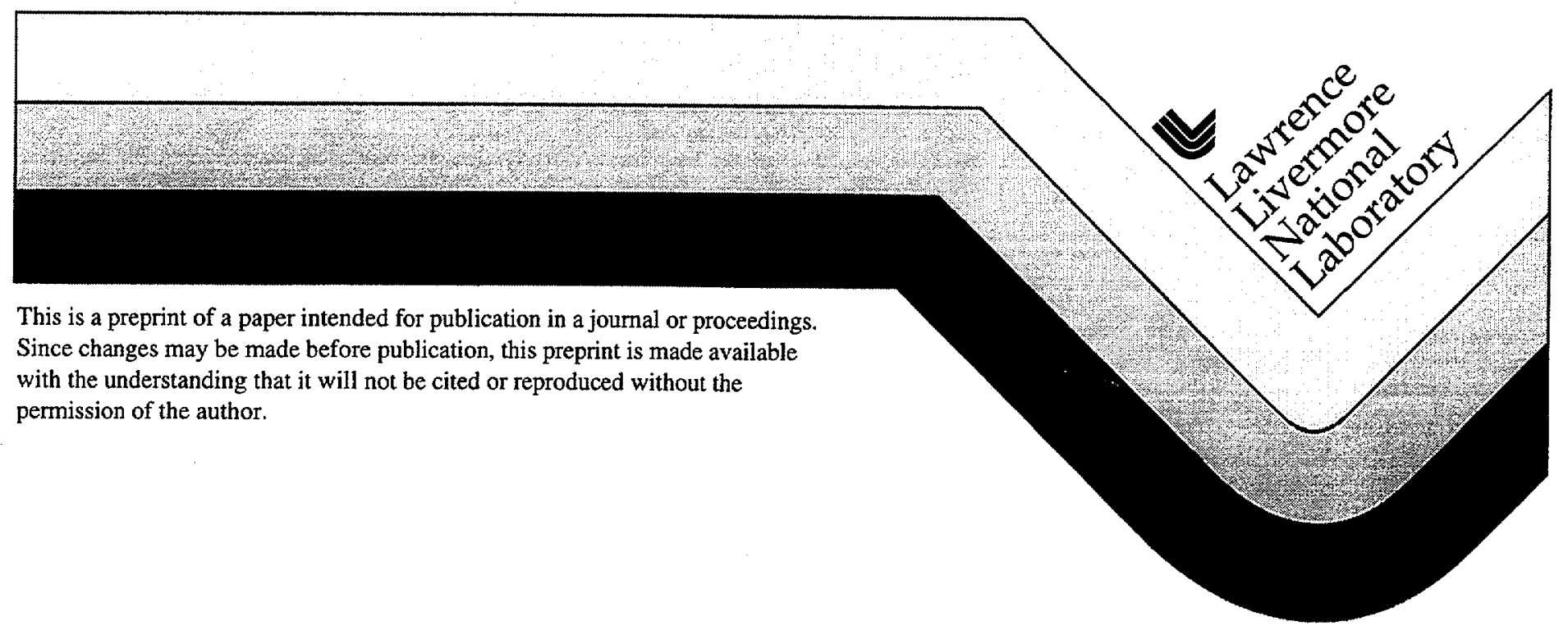




\section{DISCLAIMER}

This document was prepared as an account of work sponsored by an agency of the United States Government. Neither the United States Government nor the University of California nor any of their employees, makes any warranty, express or implied, or assumes any legal liability or responsibility for the accuracy, completeness, or usefulness of any information, apparatus, product, or process disclosed, or represents that its use would not infringe privately owned rights. Reference herein to any specific commercial product, process, or service by trade name, trademark, manufacturer, or otherwise, does not necessarily constitute or imply its endorsement, recommendation, or favoring by the United States Government or the University of California. The views and opinions of authors expressed herein do not necessarily state or reflect those of the United States Government or the University of California, and shall not be used for advertising or product endorsement purposes. 


\title{
HUMID AIR CORROSION OF YMP \\ WASTE PACKAGE CANDIDATE MATERIAL
}

\author{
Gregory E. Gdowski \\ Lawrence Livermore National Laboratory \\ Livermore, CA 94550
}

\begin{abstract}
Humid air corrosion of carbon steel under conditions of constant temperature and relative humidity was investigated. Carbon steel is a candidate material for the Yucca Mountain Site Characterization Project's Waste Packages (WP). The WPs are containers for storage of high level nuclear waste at a potential repository at Yucca Mountain, Nevada. A thermogravimetric analyzer was employed to investigate the short term corrosion of carbon steel under constant relative humidities, at elevated temperatures $\left(60-90^{\circ} \mathrm{C}\right)$, and with various surface conditions. As expected, the initial corrosion rates are greatly enhanced by the presence of deposited sodium chloride under high relative humidity conditions. The corrosion product formed with deposited sodium chloride is porous and non-adherent. However, the corrosion rate decreases with time; this suggests that the components of the deposited salt are incorporated into the corrosion products. Characterization of the corrosion product formed gave an understanding of the long term corrosion processes.
\end{abstract}

Keywords: atmospheric corrosion, carbon steel, humid air corrosion, sodium chloride, $\mathrm{NaCl}$, relative humidity 


\section{INTRODUCTION}

The Yucca Mountain Site Characterization Project is evaluating candidate materials for high level nuclear waste containers (Waste Packages) for a potential deep geologic repository at Yucca Mountain, Nevada. The potential repository is located above the water table in the unsaturated zone. The rock contains nominally $10 \%$ by volume water and gas pressure in the emplacement drifts of the repository is expected to remain near the ambient atmospheric pressure. The heat generated by the radioactive decay of the waste will raise the temperature of the waste packages and the surrounding rock. This temperature rise will liberate water from the pores and micro-fractures of the rock. Waste Package temperatures above the ambient boiling point of water are anticipated for the waste emplacement scenarios. Because the repository emplacement drifts are expected to remain at the ambient atmospheric pressure, the maximum relative humidity obtainable decreases above the boiling point of water (see Figure 1). Temperatures of the Waste Packages and the surrounding rock are expected to reach maximum temperatures within 100's of years and then gradually decrease with time. Episodic liquid water contact with the WPs is also expected; this will result in the deposition of salts and mineral scale.

An understanding of the corrosion processes that occur under constant temperature and constant relative humidity are necessary for evaluation of candidate Waste Package materials. While there is much literature on the effect of humid air on the corrosion of materials under ambient atmospheric conditions, little information is available at higher temperatures [1]. This study investigated the humid air corrosion of carbon steel in the temperature range 60 to $90^{\circ} \mathrm{C}$.

Hygroscopic salts are known to significantly enhance the corrosion of mild steel at relative humidities below $100 \%$ [1]. The aqueous salt solutions formed enable aqueous film electrochemical corrosion of the steel to occur. The severity of the corrosion is dependent on the particular salt and the relative humidity. It has been noted that, in general, the severity of attack of steel as a function of relative humidity increases significantly at $\mathrm{RH}$ values equal to or greater than the equilibrium relative humidity of the saturated salt solution. Bulk aqueous salt solutions will form at the equilibrium relative humidity. However, there is a noted increase in the corrosion of steel even at relative humidity values below the equilibrium value when compared to the corrosion in the absence of the deposited salt $[1,2]$.

The equilibrium relative humidities versus temperature of several saturated salt solutions [3] and the boiling points of several saturated salt solutions [4] are plotted in Figure 1. In terms of the cations, salts of sodium $(\mathrm{Na})$ and potassium $(\mathrm{K})$ tend to have higher equilibrium RH's (less hygroscopic) than those of calcium (Ca) and magnesium (Mg). In terms of the anions, sulfates $\left(\mathrm{SO}_{4}\right)$ have higher equilibrium $\mathrm{RH}$ 's (less hygroscopic) than those of chlorides $(\mathrm{Cl})$ and nitrates $\left(\mathrm{NO}_{3}\right)$.

For some salts, such as, sodium chloride $(\mathrm{NaCl})$, there is little change in the equilibrium $\mathrm{RH}$ as a function of temperature, this is probably because the solubility of $\mathrm{NaCl}$ 
does not change much with temperature. For other salts, such as, sodium nitrate $\left(\mathrm{NaNO}_{3}\right)$ there is almost a $20 \%$ change in the equilibrium $\mathrm{RH}$ as a function of temperature, this is probably because the solubility of $\mathrm{NaNO}_{3}$ doubles from 25 to $100^{\circ} \mathrm{C}$.

At $\mathrm{RH}$ values less than the equilibrium value, bulk aqueous salt solutions will not form. At $\mathrm{RH}$ values greater than the equilibrium value, more dilute aqueous solutions will form. The amount of water that is taken up by hygroscopic salts, such as, $\mathrm{NaCl}$, have been previously determined as a function of relative humidity [4]. At $100^{\circ} \mathrm{C}$ and $74 \% \mathrm{RH}$ (the equilibrium $\mathrm{RH}$ ), there are about $2.6 \mathrm{mg}$ of water taken up per $\mathrm{mg} \mathrm{of} \mathrm{NaCl}$. At $100^{\circ} \mathrm{C}$ and $85 \% \mathrm{RH}$, there are about $4.4 \mathrm{mg}$ of water taken up by per $\mathrm{mg}$ of $\mathrm{NaCl}$. At $100^{\circ} \mathrm{C}$ and $91 \%$ $\mathrm{RH}$, there are about $7 \mathrm{mg}$ of water taken up by per $\mathrm{mg}$ of $\mathrm{NaCl}$.

The corrosive action of deposited salts, such as $\mathrm{NaCl}$ and $\mathrm{Na}_{2} \mathrm{SO}_{4}$, on carbon steel is well documented [1]. Under normal atmospheric conditions, it is recognized that the effectiveness of sustaining the corrosion processes decreases with time for a given amount of initially deposited salt. It is documented that chloride ions are incorporated into the iron oxide akaganeite under marine conditions [5]. Sulfate has been identified within solid corrosion products [6]. The mineral jarosite, $\mathrm{NaFe}_{3}(\mathrm{OH})_{6}\left(\mathrm{SO}_{4}\right)_{2}$ or $\mathrm{KFe}_{3}(\mathrm{OH})_{6}\left(\mathrm{SO}_{4}\right)_{2}$, has been suggested as an example of a potential iron and sulfate containing compound that could form during corrosion [5]. Graedel and Frankelthal [5] have discussed the topic of mineral formation during corrosion in some detail.

\section{EXPERIMENTAL}

Test specimens were made of 1020 carbon steel and ASTM A516 Gr 55. Test specimen dimension were nominally 1.5 in $\times 0.5$ in $\times 0.062$ in. Clean specimens and specimens with deposited $\mathrm{NaCl}$ were tested.

Experiments were performed using an extensively modified Cahn Model TG 131 thermogravimetric analyzer. The resolution of the analyzer was about $40 \mu \mathrm{g}$. The reaction chamber was a double walled glass cylinder. Temperature and relative humidity were measured in the reaction chamber by a combined temperature humidity sensor. Temperature was maintained by flowing a constant temperature fluid through the outer annulus of the glass reaction chamber. Temperature was maintained to less than $\pm 0.5^{\circ} \mathrm{C}$.

Humid air was obtained by either bubbling cleaned laboratory air through a column of water or by use of a liquid injection system. In the liquid injection system, a micropump feed controlled amounts of water to a vaporizer, and then a carrier gas (air) transported the vaporized water to the reaction chamber. In both cases, the plumbing to the reaction chamber was heated to avoid condensation of water. Relative humidity was maintained to better than $\pm 4 \%$.

Salts were deposited utilizing two techniques. Initially salts were deposited by immersing the specimen in $\mathrm{NaCl}$ saturated $50 \%$ water $/ 50 \%$ acetone solution, and then 
drying the specimens in hot air. The process was repeated until the desired amount of salt was deposited. In the second technique, salts were deposited by placing the specimens in a salt aerosol stream, and then drying in hot air. The aerosol was formed by an atomizer apparatus. The amount of salt deposited was nominally $5 \mathrm{mg}$.

Specimens were tested under nominally constant temperature and constant relative humidity conditions. Test durations were typically 7 to 14 days. Specimens were initially brought to the test temperature in low humidity air. After the temperature was stabilized the humidified air was introduced. Relative humidity was controlled by varying the flow rate of the carrier gas in the vaporizer or by mixing dry air with the humidified air from the bubbler.

Temperature and relative humidity in the reaction chamber, and change in the specimen weight were all recorded as a function of time by a computer.

\section{RESULTS AND DISCUSSION}

\section{Clean and polished specimens}

Clean polished $A 516$ specimens were exposed in the temperature range 60 to $90^{\circ} \mathrm{C}$ to relative humidities up to $90 \%$. No oxidation of the specimens was detected for the $\mathrm{RH}<$ $75 \%$ for the test conditions. At nominally $90 \%$ there was typically a small increase in the specimen weight and some visible oxidation of the specimens. The small amount of oxide which formed was adherent. The weight gain of a specimen at a temperature of $75^{\circ} \mathrm{C}$ and $90 \% \mathrm{RH}$ as a function of time is shown in Figure 2.

Numerous studies have investigated the adsorption of water as a function of relative humidity. On iron, water adsorption has been investigated up to $85^{\circ} \mathrm{C}$ and $95 \% \mathrm{RH}$ [7]. At about $90-95 \% \mathrm{RH}$ water adsorption is less than $5 \times 10^{-7} \mathrm{~g} / \mathrm{cm}^{2}$. Averaged over the surface this corresponds to thickness of less than $5 \times 10^{-3} \mu \mathrm{m}$ (less than 20 monolayers of water). This estimate of water film thickness is obviously an over simplification of water adsorption characteristics, since water will form clusters and preferentially adsorb at high energy sites. However, it does indicate that water adsorption even at high relative humidity values is limited to relatively thin thicknesses. Oxygen resupply from the atmosphere and subsequent transport through water films of such thicknesses will be fast.

The electrochemical oxidation / corrosion of iron is limited by the conductivity of the oxide which is formed $[8,9]$ because the oxygen reduction reaction occurs on the high conductivity oxide:

$$
\mathrm{O}_{2}+\mathrm{H}_{2} \mathrm{O}+2 \mathrm{e}^{-} \rightarrow 2 \mathrm{OH}^{-}
$$

Magnetite $\left(\mathrm{Fe}_{3} \mathrm{O}_{4}\right)$ has a much higher conductivity than the $\mathrm{Fe}$ (III) oxides, hematite $\left(\mathrm{Fe}_{2} \mathrm{O}_{3}\right)$ and geothite $(\alpha-\mathrm{FeOOH})$. It is expected that under the oxidizing conditions of the thin 
aqueous films that iron would be oxidized to Fe(III) and would then quickly precipitate because $\mathrm{Fe}$ (III) compounds have limited aqueous solubility except under acidic conditions. Scanning electron microscopy indicated a thin dense oxide formed under these conditions. There was an insufficient amount of oxide for identification by $\mathrm{X}$-ray diffraction.

\section{Specimens with deposited salt $(\mathrm{NaCl})$}

A516 carbon steel specimens with deposited $\mathrm{NaCl}$ were exposed to relative humidities of up to $90 \% \mathrm{RH}$ at nominally $80^{\circ} \mathrm{C}$. The results are plotted in Figure 2. For comparison, the data for a clean specimen exposed to $90 \% \mathrm{RH}\left(75^{\circ} \mathrm{C}\right)$ is also included in the figure. At all values of relative humidity tested there were weight gains recorded. Visual observation of the specimens during testing indicated that most of the weight gain was due to oxidation / corrosion of the specimen. Brownish oxide formation was observed simultaneously with the weight gain increases. The weight gain became significantly more rapid when the relative humidity was increased above $48 \%$. Note that the equilibrium relative humidity of a saturated $\mathrm{NaCl}$ aqueous solution is about $75 \%$.

For the $78 \% \mathrm{RH}$ test, the weight gain data showed an initial rapid increase, followed by a more gradual increase, and finally a region of no increase or a slight decrease. Visually it was observed that the amount of corrosion / oxidation product was increasing with time under these conditions. The slight decrease of weight gain was in part due to some spalling of the corrosion product off the vertical specimens. It should be noted that with the deposited $\mathrm{NaCl}$ no visible water film was observed at any relative humidity. This was probably due to the rapid corrosion / oxidation of the specimen because of the extremely aggressive conditions on the surface. The sorbed water would form very concentrated sodium chloride brine, and in addition, ready availability of oxygen from surrounding air made the aqueous conditions oxidizing.

The corrosion / oxidation product that formed on the specimens with deposited $\mathrm{NaCl}$ was nonadherent. Scanning electron microscopy of the surfaces showed that the oxide had the characteristic whisker structure of the chlorine containing oxide akaganeite [10]. This oxide has been identified in corrosion products formed on carbon steels in marine environments [5].

An indication of the extent of the accelerating corrosion effect of relative humidity is illustrated by the rate of the initial weight gain of the specimens versus time. This data is listed in Table 1. It is expected that these rates would change as a function of the amount of salt deposited, but the trend does illustrated the accelerating effect of increasing relative humidity. There is a three order of magnitude increase in the initial weight gain rate upon increasing relative humidity from $48 \%$ to $88 \% \mathrm{RH}$. At a nominal value of $90 \% \mathrm{RH}$, there was almost a four order of magnitude increase in weight gain rate when salts were present than for the clean surface test. Part of the weight gain increase is due to water sorption, however, as noted above, the water sorption could contribute about $4.4 \mathrm{mg}$ per $\mathrm{mg} \mathrm{NaCl}$ to the weight gain at $85 \% \mathrm{RH}$. Water sorption into the porous structure of the corrosion product may also contribute somewhat to weight gain. 
Table 1. Initial weight gains of carbon steel specimens covered with deposited sodium chloride at $80^{\circ} \mathrm{C}$

\begin{tabular}{cc}
\hline Relative Humidity $(\%)$ & $\mathrm{mg} / \mathrm{hr}$ \\
\hline $90\left(75^{\circ} \mathrm{C} ;\right.$ no deposited salt $)$ & 0.004 \\
48 & 0.02 \\
63 & 2.3 \\
78 & 6.2 \\
88 & 38 \\
\hline
\end{tabular}

\section{CONCLUSIONS}

In the absence of deposited salts the short term oxidation of carbon steel in high relative humidity (up to $90 \% \mathrm{RH}$ ) air is slow at temperatures of 60 to $90^{\circ} \mathrm{C}$. With deposited sodium chloride, carbon steel at $80^{\circ} \mathrm{C}$ is susceptible to corrosion oxidation at even $48 \% \mathrm{RH}$. The initial degradation is accelerated at $63 \% \mathrm{RH}$ and it significantly increases further at $\mathrm{RH}$ values above the equilibrium relative humidity of a saturated $\mathrm{NaCl}$ solution.

With time the corrosive effect of a small fixed amount of sodium chloride decreases. It is thought that this is due to the incorporation of the components of the salt into the corrosion product. The long term stability of this corrosion product is of interest because liberated salt would then be available for further corrosion.

\section{ACKNOWLEDGMENTS}

Work performed under the auspices of the U.S. Department of Energy by Lawrence Livermore National Laboratory under Contract W-7405-ENG-48. This work is supported by Yucca Mountain Site Characterization Project, LLNL.

The author acknowledges the technical assistance of John Estill, Steve Gordon, Rich Green, and Kirk Staggs.

\section{REFERENCES}

1. V. Kucera and E. Mattsson, "Atmospheric Corrosion" in Corrosion Mechanisms, F. Mansfeld, ed., Marcel Dekker, Inc., New York, 1987, p. 211.

2. S.J. Duly, J. Soc. Chem. Ind., Vol. 69, 1950, p. 304.

3. L. Greenspan, Journal of Research of the National Bureau of Standards, Vol. 81A, No. 1,1977 , pp. 89-96. 
4. E.W. Washburn, editor-in-chief, International Critical Tables of Numerical Data, Physics, Chemistry and Technology, McGraw-Hill Book Company, Inc. New York, 1928.

5. T.E. Graedel and R.P. Frankenthal, J. Electrochem. Soc., Vol. 137, 1990, p. 2385.

6. J.-L. Leibenguth and M. Cohen, J. Electrochem. Soc., Vol. 119, 1972, p. 987.

7. S. Lee and R.W. Staehle, Corrosion, Vol. 53, 1997, p. 33.

8. U.R. Evans and C.A.J. Taylor, Corrosion Science, Vol. 12, 1972, p. 227.

9. M. Stratmann, Ber. Bunsenges Phys. Chem. Vol. 94, 1990, p. 626.

10. U. Schwertmann and R.M. Cornell, Iron Oxides in the Laboratory; Preparation and Characterization, VCH, New York, 1991. 
Equilibrium Relative Humidities and Boiling Points of Saturated Salt Solutions

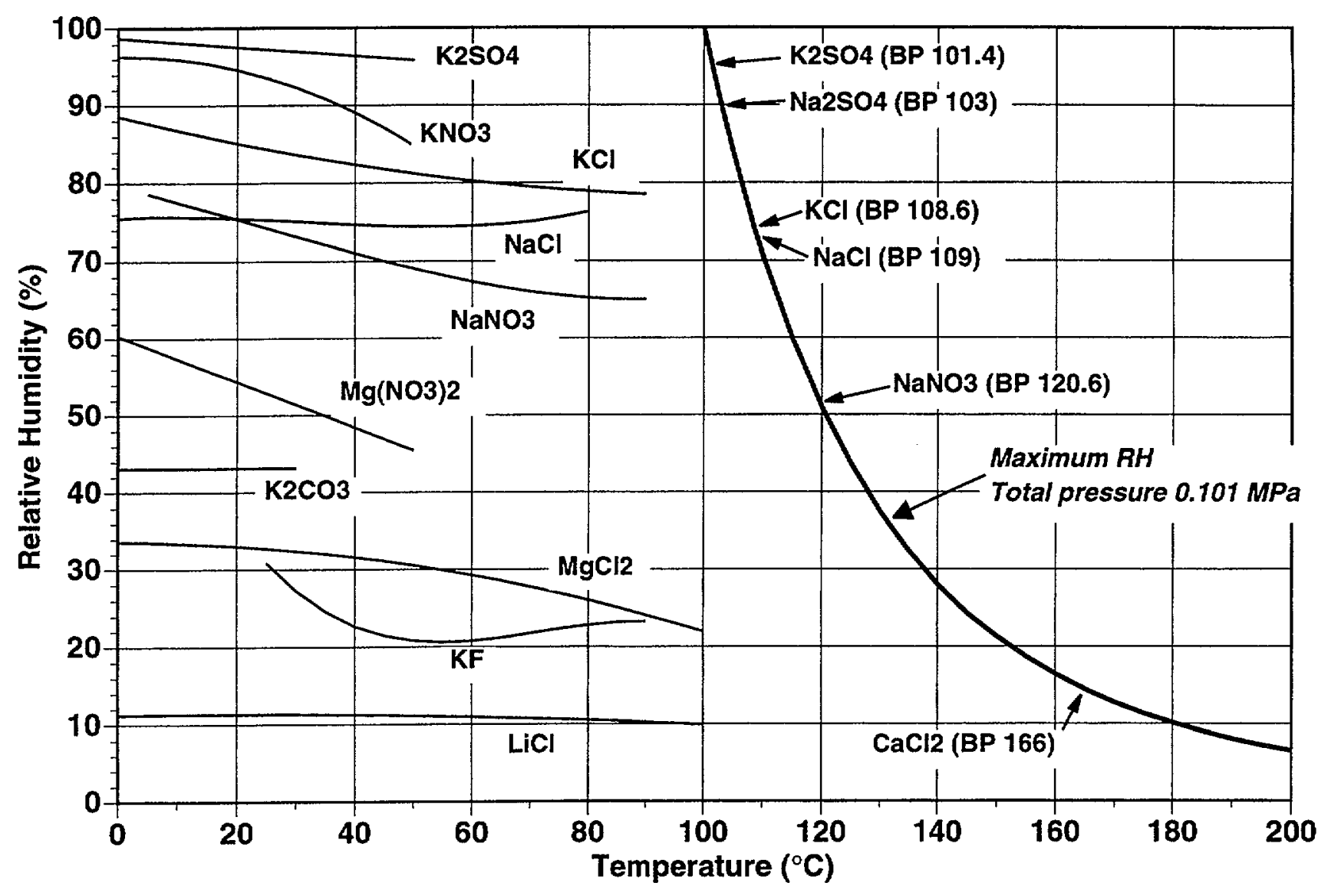




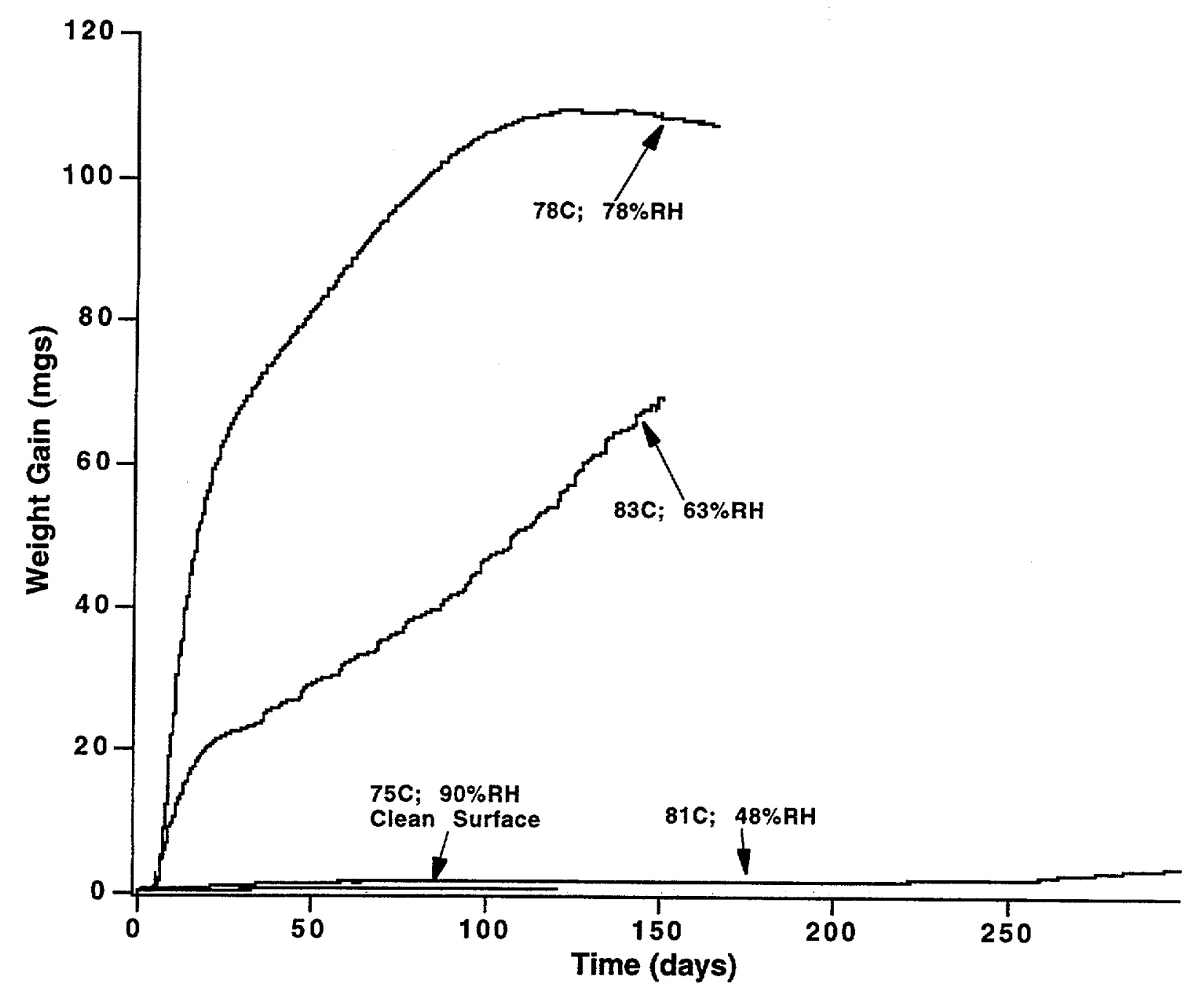

Figure 2. Weight gain of salt covered A516 carbon steel versus time as a function of relative humidity. Specimens had nominally $5 \mathrm{mg}$ of deposited $\mathrm{NaCl}$. Also included for comparison is the plot for a clean specimen exposed to $90 \% \mathrm{RH}$. 
